Розділ І. Ціннісні орієнтири духовно-інтелектуального виховання, розвиток духовно-інтелектуальних якостей особистості в умовах співпраці й інклюзії

\title{
ДИТЯЧА КНИГА ЯК ОСНОВА ДУХОВНО- ІНТЕЛЕКТУАЛЬНОГО РОЗВИТКУ ДІТЕЙ ДОШКІЛЬНОГО ВІКУ
}

\begin{abstract}
Полежака Д. В.
здобувач третього (освітньо-наукового) рівня вищої освіти, Харківський національний педагогічний університет імені Г. С. Сковороди, м. Харків, Україна

У статті йдеться про особливості використання дитячої книги як засобу духовно-інтелектуального розвитку особистості. Вказано на провідні характеристики книги, щуо мають забезпечувати духовноінтелектуальне зростання дитини та сприяють формуванню ї̈ читацьких інтересів. Визначено низку суперечностей, які виникають сьогодні між видавцем дитячих книжок та споживачами.
\end{abstract}

Ключові слова: духовне виховання, сучасна дитяча книга, комунікачія, розвиток мовлення.

The article deals with the peculiarities of the use of children's books as a means of spiritual and intellectual development of the individual. The leading characteristics of the book are indicated, which should ensure the spiritual and intellectual growth of the child and contribute to the formation of its reading interests. A number of contradictions that arise today between the publisher of children's books and consumers have been identified.

Keywords: spiritual education, modern children's book, communication, development of speaking skills.

Дитяча книга покликана відображати глибинний світ дитини. Вона здатна вплинути на мовленнєвий розвиток особистості, ii світогляд, а також сформувати духовно-інтелектуальний потенціал. Літературнохудожні твори відіграють важливу роль у вихованні емоційного інтелекту дитини, а також впливають на процеси соціалізації.

На сучасному етапі суспільство більше уваги приділяє інтелектуальному розвитку дітей, забуваючи про важливість духовно-морального та естетичного виховання. Тому інтерес до дитячої літератури значно зменшився. У цьому питанні значну роль також відіграє процес інформатизації суспільства. Батьки менше часу проводять разом 3 дітьми, обираючи мультфільми у якості штучного замінника процесів комунікації, відповідно, ними втрачається розуміння важливості духовного розвитку дітей. 
Питанням виховання дітей дошкільного віку засобами дитячої літератури сьогодні займаються А. Смець, І. Луценко, Е. Огар та інші; комплекс питань, пов'язаних із визначенням змісту роботи, завдань, форм, методів, прийомів ознайомлення дошкільників із художньою літературою розглянуто в працях А. Богуш, А. Виноградової, Н. Гавриш, Л. Гурович, Р. Жуковської, Н. Карпинської, М. Коніної, О. Лещенко, О. Ушакової та інших. Особливості сприймання дітьми змісту художніх творів розкрито в дослідженнях психологів О. Запорожця, Д. Ельконіна, О. Никифорової, С. Рубінштейна, П. Якобсона та інших. Завдання дитячої літератури, іiі специфіка розглядались також у доробку відомих українських поетів і письменників: Лесі Українки, Івана Франка, Наталії Забіли, Грицька Бойка, Остапа Вишні. Однак і сьогодні залишається не вирішеним коло питань, що стосуються створення книги, котра стане засобом розвитку дитини, інструментом залучення іiї до продуктивного читання.

Мета статті - проаналізувати теоретичні питання використання дитячої книги як засобу для духовно-інтелектуального розвитку дитини.

Дитяча книжка покликана створювати духовно-емоційне середовище для становлення особистості дитини, розвитку людського в ній, a, отже, утвердження гуманного смислу буття, гідності й розуму людини, іiі прав на земне щастя, вільний вияв природних людських почуттів і здібностей. Завдання дитячої книги забезпечити перемогу гуманного світогляду над антигуманним, подальший соціальний, духовний прогрес людини. 3 нею також слід пов'язувати розвиток майбутньої цивілізації. Завдання, сформульоване А. Швейцером для сучасників, — «досягнути справжньої доброти» - можна виконати, лише залучивши до освітнього процесу кращі художні твори, створені для дітей [1, с. 203].

На підставі аналізу сучасних дитячих книжок можемо визначити провідні характеристики книги як засобу духовно-інтелектуального зростання, а саме: наповнення їі особливим духовним змістом, якісні ілюстрації, урахування вікової аудиторії, доступність та яскравість викладу. На підтвердження цієї тези маємо думку Е. Огар, що зауважує: уявлення видавців про читацькі потреби і можливості потенційної читацької аудиторії надзвичайно узагаль- 
Розділ І. Ціннісні орієнтири духовно-інтелектуального виховання, розвиток духовно-інтелектуальних якостей особистості в умовах співпраці й інклюзії

нені й неточні. Вони побудовані здебільшого на досить спрощеній віковій диференціації, з орієнтацією на таку собі абстрактну дитину без явних ознак статі, національності, усередненого психологічного, розумового, емоційного та освітнього рівня, єдиного на всі часи «стандарту» [2, с. 87].

Дослідник робить висновок, що не по-сучасному виглядає «дзеркало», покликане відтворювати світ сучасної української дитини, бо книга лише тоді здатна впливати на виховання гармонійної особистості, тобто повною мірою реалізувати свою основну соціальну функцію, коли приходить до дитини в потрібний час. На кожному етапі життя дитина мала б отримувати свою книгу - книгу, яка б відповідала іiі читацьким потребам - торкалася найважливіших для цього періоду тем, справді зацікавлювала.

Міркувань щодо майбутнього української дитячої книжки, зокрема, чинників її конкуретноздатності в протистоянні з «авдіовізуальною культурою» $є$ чимало, і вони вимагають докладного висвітлення. Результатом нашої роботи стало визначення низки суперечностей, що виникають сьогодні між видавництвом та споживачем, а саме: видавництво прагне реалізувати продукцію, незважаючи на якість, а споживач прагне якості за доступною ціною; видавництво орієнтується на загальні запити суспільства, а споживач — на індивідуальні; видавництво тяжіє до традиційних видів книжкового продукту, у той час як споживачі хочуть мати мультивекторний продукт - книгу, що поєднує кілька функцій. У цьому процесі провідна роль належить батькам, вихователям, освітнім організаціям та установам. Сьогодні залучення до читання має стати ще й одним із напрямів освітньої політики держави, яка має опікуватися формуванням свідомого громадянина та патріота.

Отже, популяризація дитячої книжки як потужного інструменту духовно-інтелектуального розвитку дітей дошкільного віку повинна стати провідною не тільки у соціальній політиці держави, а й у свідомості сучасних батьків. Адже моральне виховання дитини є важливим складником розвитку особистості. Від нього буде залежати якою людиною малюк стане у майбутньому та які життєві принципи у нього будуть сформовані. У подальших дослідженнях потрібно враховувати особливості розвитку сучасних дітей та модернізувати під їх потреби дитячу книжку. 
Духовно-інтелектуальне виховання і навчання молоді в XXI столітті

\section{Список використаних джерел:}

1. Луценко I., Роль дитячої книжки у вихованні людяності в дітей дошкільного віку. Педагогічна освіта: теорія і практика : Збірник наукових праць. Кам'янець-Подільський національний університет імені Івана Огієнка. Інститут педагогіки НАПН України. №21. Ч.2. Кам’янець-Подільський, 2016. 304 c.

2. Огар Е. І., Сучасна українська дитяча книга і світ дитинства. Іноземна філологія. 2007. №119. с.84-87. 